\title{
South African government rejects AZT advice
}

Cape Town

The South African government announced last week that it has rejected two reports commissioned from its Medicines Control Council (MCC) on the safety of the antiretroviral drug AZT (zidovudine) after public statements by political leaders on its potential hazards.

Both reports are believed to endorse the use of AZT. But health minister Manto Tshabalala-Msimang told a press briefing held after last week's opening of parliament that the government is not currently prepared to release their contents. She also refused to reveal the findings of a third report compiled by the council, which she said she had only received on 31 January.

The reports were commissioned last October after president Thabo Mbeki had defended the government's decision not to make AZT freely available in the public health system (see Nature 402, 3; 1999). His argument that there was a large volume of scientific literature indicating that the drug's toxicity is a danger to health led to an outcry from AIDS activists and researchers in both South Africa and abroad.

Helen Rees, director of the reproductive health research unit at Johannesburg's Baragwanath Hospital and chair of the MCC, said in December that the first report - which she described at the time as "fairly superficial" - found that the benefits of AZT outweighed its risks, and that use of the drug was justified. Rees has not been available for comment this week.

But Tshabalala-Msimang said that the first two reports "were not to our satisfaction". In particular, she said they had not addressed the risk-benefit assessments of using anti-retroviral drugs in the way requested by her department. She has now asked the MCC "to make available to us information that would assist in determining the risk-benefit assessments".

The health minister added that she had read only the first few pages of the third report, and was therefore "not quite ready" to comment on it.

But she hoped that this report had addressed the risk-benefit issues in the way that the others had not. Asked if she would make the report public, she replied that legislation made provision for such documents to be made public "when we are finished working on them, if they are required to be published".

Tshabalala-Msimang is also believed to have received two further reports, one commissioned by the government from the Medicines Research Council, and one from the World Health Organization. Both are understood to recommend the use of AZT in reducing mother-to-child transmission of

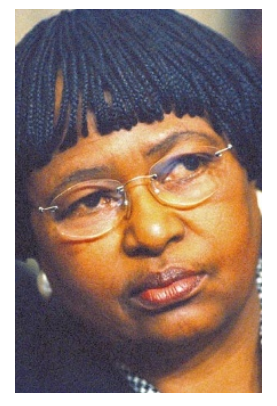

HIV/AIDS - a procedure that the government has so far refused to sanction.

The health minister said that the National AIDS Council, which met for the first time last week, has agreed to set up five technical task teams whose briefs Tshabalala-Msimang: would match the priorwants more details. ities of the national AIDS strategic plan adopted in January: prevention; care, treatment and support; research; human rights and legal issues; and social mobilization.

In a later speech to parliament, Tshabalala-Msimang said she and provincial health ministers had accepted guidelines for treat- ment, throughout the public health system, of "opportunistic" infections that affect HIV/AIDS patients.

But the government's efforts remain under heavy fire from AIDS activists. Mark Heywood, a member of the executive of the AIDS consortium, the country's largest coalition of non-governmental AIDS organizations, criticized both the health minister and the president for failing to meet their legal and moral responsibilities to improve access to health care in South Africa.

"They are wilfully ignoring the best scientific advice, internationally and locally, on the safety and benefits of providing AZT through the public health sector," he says. "The immediate cost of this impasse is measured in thousands of unnecessary infant HIV infections for which they now carry a very direct responsibility." Michael Cherry

\section{Consortium aims to kick-start TB research}

\section{Cape Town}

A loose consortium of leading scientists, donor agencies and pharmaceutical companies agreed last week to create a joint venture between the public and private sectors to relaunch research into drugs that are able to combat tuberculosis (TB).

Meeting for the first time in Cape Town, South Africa, the Global Alliance for TB Drug Development agreed to draft a scientific blueprint by June of this year. This would aim to reach a consensus on research priorities among participating institutions, and coordinate funding for them.

One-third of the world's population - some 2 billion people - are infected with Mycobacterium tuberculosis, the bacterium that causes the disease, and 16 million people have active TB. AIDS activates the dormant form of the disease, and the proportion of carriers who develop active TB is increasing there are 8 million new cases, and 2 million deaths, each year.

Multidrug resistance is also spreading rapidly throughout the world, raising the spectre of untreatable TB. The last new drug for TB was introduced over 30 years ago, and industry has been reluctant to invest in discovering new families of drugs because of the financial risks of investing in products destined mainly for developing countries.

The meeting was convened by the Rockefeller Foundation, and co-sponsored by the US National Institutes of Health, the Bill and Melinda Gates Foundation, the Wellcome Trust, the World Health Organization (WHO), the World Bank, the US Centre for Diseases Control and several other donor and research agencies and nongovernmental organizations.

The proposed alliance, which is similar to the Multilateral Initiative on Malaria (see Nature 388, 219 \& 390, 209; 1997), would be coordinated by the WHO.

Several scientists at the meeting pointed out the apparent irony that recognizing the need for new tools has in the past been inhibited by the WHO, which had argued strongly that TB could be contained by the WHO's DOTS strategy (Directly Observed Therapy, Short Course), a cocktail of antibiotics administered daily under medical supervision.

The impractability of administering this labour-intensive procedure in developing countries and the emergence of multidrug resistance have prompted a U-turn at the WHO. In a video address to the meeting, Gro Harlem Brundtland, WHO director- general, said that, although DOTS had helped, it was no longer enough and "it is high time to find new and more effective drugs". Ideally, a drug should have a shorter course and require less supervision by health workers, she said.

As a first step towards launching a common drugdiscovery programme for TB between the public and private sectors, akin to the New Medicines for Malaria Initiative, the alliance will prepare a 'pharmaco-economics' report by October that will assess in detail the size of the market, current investment, and gaps in corporate research and development.

Giorgio Roscigno, medical director of Hoechst Marion Roussel, told the meeting that one reason that companies have not invested in drugs to combat tuberculosis is that they have underestimated the market.

The alliance plans to use the report as the basis for a business plan for a joint drug-discovery programme that would be announced in December, with the alliance being formally created in early 2001. The programme has the ambitious goal of registering a new drug for TB by 2007 and a second by 2012 . Declan Butle 